\title{
Studies on Hypoxia
}

\section{$X$. Effects of Synthetic Polyribonucleotides on Pancreas from Hypoxic and Control Rats: An Electron Microscopic and Biochemical Study}

\author{
Y. G. Kim ANd S. S. HaN \\ Departments of Anatomy and Oral Biology, The University of Michigan, \\ Schools of Medicine and Dentistry, Ann Arbor, Michigan 48104
}

Received November 15, 1974

\begin{abstract}
Young male Sprague-Dawley rats were paired according to weight, and experimental animals were placed in an environmental chamber which was supplied with a continuous flow of $88 \% \mathrm{~N}_{2}$ and $12 \% \mathrm{O}_{2}$ for 7 days. The paired control animals were treated identically except that a flow of ambient air was made available in place of the gas mixture. One half of each of the experimental and control rats was given an intraperitoneal injection of polyadenylic and polyuridylic acids [poly A:U ( $1 \mathrm{mg} / \mathrm{kg}] 24 \mathrm{hr}$ prior to sacrifice. All animals were given an injection of $\mathrm{L}$ phenylalanine- ${ }^{-3} \mathrm{H}(2 \mu \mathrm{Ci} / \mathrm{g}$ spact; $5 \mathrm{Ci} / \mathrm{mmale})$ at $60 \mathrm{~min}$ prior to sacrifice. Tissues were prepared for microscopic observation by perfusion fixation with $2 \%$ formaldehyde derived from paraformaldehyde and embedding in epoxy resin in a routine manner. In biochemical work, tissues were analyzed for amylase, DNA, and protein. Radioactivity in acid-precipitable and soluble fractions was determined by scintillation spectroscopy. The ultrastructural aspects of pancreatic acinar cells from hypoxic rats confirmed findings from earlier studies from this laboratory and showed a general reduction in size and organizational complexity of cytoplasmic organelles that are concerned with exportable protein biosynthesis. In poly (A:U)-treated rats, ultrastructural changes in pancreatic acinar cells included a reduction in the number of mature zymogen granules and a marked enlargement of Golgi apparatus. Biochemically, tissues from poly $(\mathrm{A}: \mathrm{U})$-treated rats showed an enhanced protein synthesis despite a decrease in the total protein and amylase contents, indicating a facilitated release of secretory proteins by poly $(A: U)$. Although similar effects were observed both in control and hypoxic animals, the cells from the experimental rats showed more pronounced changes. It is concluded that (poly (A:U) stimulates protein synthesis by pancreatic acinar cells and that such stimulation is more pronounced in the pancreas from rats that have been exposed to hypoxia.
\end{abstract}

\section{INTRODUCTION}

In recent years synthetic polyribonucleotides have been used in a number of experimental work. They have produced a marked enhancement of antibody protein synthesis (Braun et al., 1971; Cone and Johnson, 1972) and increased the number of antibody-forming cells responding to antigenic stimulation (Braun et al., 1967; Cone and Johnson, 1972). Similarly, an enhancement of protein synthesis by synthetic polyribonucleotides has been well documented in the area of interferon production in bacterial systems (review by Colby, 1971). Despite these interesting results, their mechanism of action in eliciting stimulatory 
effects remains to be determined. Schell (1971) has observed that polyadenylic and polyuridylic acids [poly ( $A: U)$ ] entered Fhrlich ascites tumor cells without separation of the base pairing and without breakage of the polymeric strands. The uptake of synthetic poly $(\mathrm{A}: \mathrm{U})$ by Ehrlich ascites tumor cells was shown to depend on the $\mathrm{pH}$ of the incubation medium (Schell, 1972). Furthermore, it was shown that the cyclic AMP levels after polyribonucleotide administration were increased in stimulated lymphoid organs (Braun et al. 1971).

Preliminary work in our laboratory has suggested that poly (A:U) might stimulate secretory release by pancreatic cells in normal and fluorouracil-treated rodents and that an enhancement in protein synthesis occurs in cells that are damaged by the administration of 5-fluorouracil (Kim and Han, 1972; Han, 1973 and Han and Hwang, 1974).

In a previous paper we reported that, under prolonged hypoxic condition, a drastic increase in the incorporation of radioactive amino acids into total protein and a reduction of amylase content in the pancreatic cells were found (Kim and Han, 1975). These results were taken to suggest that a chronic hypoxic stress might cause a suppression of exportable protein synthesis, but at the same time may induce other cytoplasmic protein production through changes in membrane permeabilities.

The present study aims to explore the effects of synthetic poly ( $A: U$ ) on the fine structure and functioning of pancreatic acinar cells after a prolonged hypoxic exposure.

\section{MATERIALS AND METHODS}

Animals. A total of 84 male Sprague-Dawley rats weighing 196-238 g were used throughout this study. The rats were purchased from Spartan Farms (Spartan Research Animals, Haslett, MI) and housed in airconditioned animal quarters of the Department of Anatomy, The University of Michigan. They were fed Purina Rat Chow and tap water ad lib. and provided with $14 \mathrm{hr}$ of light and $10 \mathrm{hr}$ of dark. Animals were allowed to adapt to this environment for 4 days prior to the experiment. Experimental and control rats were pair-fed in the usual manner (Pfrender, 1973). All animals were starved overnight prior to sacrifice. In order to minimize circadian rhythmic effects, the rats were killed at 9:00 AM.

Environment. Experimental animals were placed for 7 days in a customfabricated hypoxic chamber which was gassed with continuous flow of $12 \%$ oxygen and $88 \%$ nitrogen under a pressure of less than 2 psi above the atmospheric pressure at a constant temperature of $20 \pm 1^{\circ} \mathrm{C}$ (Morawa, 1973). The oxygen tension in the chamber was intermittently monitored with an oxygen analyzer (Scientific Products). Carbon dioxide was removed with soda lime traps. The control animals were kept in an identical chamber, but ambient air was circulated in place of the gas mixture.

Dosage and administration of polyribonucleotides and radioactive amino acid. Polyadenylic acid, potassium salt [poly (A)] and polyuridylic acid, potassum salt [poly (U)] were purchased from Miles Laboratories, Inc., Elkhart, IN. An equimolar mixture of poly $A$ and poly $U$ was made to form a homopolymer of poly (A:U) in $0.15 \mathrm{M} \mathrm{NaCl}$. The average of molecular weight of both nucleotide preparations was approximately 100,000 containing $2.29 \mu M$ of phosphorous per mg. They were mixed at $30 \mathrm{~min}$ prior to injection. The poly (A:U) mixture was 
injected intraperitoneally in the amount of $1 \mathrm{mg} / \mathrm{kg}$ of body weight at $24 \mathrm{hr}$ before sacrifice. This dose was selected on the basis of (1) data from immunologic adjuvant studies (Johnson et al., 1968) and (2) several preliminary experiments which produced favorable results with this dose. The same volume of $0.15 \mathrm{M} \mathrm{NaCl}$ was injected to all animals not receiving poly (A:U).

Phenylalanine was chosen as the precursor for studying protein synthesis partly because of its relatively high rate of incorporation by the pancreas, and partly because of its possible use in later studies of ribosomal changes, as it allows the use of poly $\mathrm{U}$ as an exogenous messenger in polyphenylalanine synthesis in cell-free systems. Tritium-labeled phenylalanine ( ${ }^{3} \mathrm{H}$-phe) was obtained from New England Nuclear Corporation. An intraperitoneal injection of ${ }^{3} \mathrm{H}$-phe in the amount of $2 \mu \mathrm{Ci} / \mathrm{g}$ of body weight (sp act, $5 \mathrm{Ci} / \mathrm{mmole}$ ) was given $60 \mathrm{~min}$ prior to sacrifice.

Preparation of tissues for light and electron microscopy. At the time of sacrifice the animals were ancsthetized using a saline solution of chloral hydratc ( $3.5 \%$ chloral hydrate, $1 \mathrm{ml}$ per $100 \mathrm{~g}$ of body weight) given intraperitoneally $5 \mathrm{~min}$ before vascular perfusion with the fixative. In preparing for perfusion, the heart was exposed by making two vertical incisions lateral to the right and left internal thoracic arteries. The rats were perfused with prewarmed $2 \%$ solution of paraformaldehyde in $0.1 \mathrm{M}$ cacodylate buffer at $\mathrm{pH} 7.4$, containing $4.5 \%$ sucrose. Pieces of the pancreas were removed after perfusion and fixed in the same fixative for $2 \frac{1}{2} \mathrm{hr}$.

After aldehyde fixation, the tissue blocks were postfixed for $1 \frac{1}{2} \mathrm{hr}$ in $1 \% \mathrm{OsO}_{4}$ in the same buffer, and dehydrated through serially graded ethanols and propylene oxide prior to infiltration with a monomeric mixture of epoxy resins according to Luft (1961).

For light microscopy 1- $\mu$ m-thick sections from all blocks were made on an LKB Ultrotome I. The sections were staincd with $\mathrm{I} \%$ toluidinc bluc in dilutc (1/10) veronal acetate buffer at $\mathrm{pH} 9.0$ and mounted with Permount. The photomicrographs were taken with a Zeiss photomicroscope.

The preparation of tissues for electron microscopy was made by cutting selected blocks on an LKB Ultrotome III. Ultrathin sections of 500-800 $\AA$ were collected on 300-mesh grids, and stained with uranyl acetate and lead citrate (Reynolds, 1963). All observations were made in a Hitachi HS-8 electron microscope.

Estimation of nucleolar index. The nucleolar index was estimated by counting the number of nucleoli present in approximately 4500 nuclei of the pancreatic acinar cells of $1-\mu \mathrm{m}$-thick sections for each group. This represented counting 100 cells each from nine randomly selected sections from five separate rats. The results were tabulated by using the following formula:

$$
\text { Nucleolar index }=\frac{\text { Number of nucleoli }}{\text { Number of nuclei }} \times 100
$$

The significance of differences between groups were evaluated by using the Student $t$ test.

Biochemical analyses. The incorporation of ${ }^{3} \mathrm{H}$-phe was determined by using a procedure modified from that of Hinrichs, Petersen, and Baserga (1964). For this purpose, three rats for each group were used. Sixty minutes after injection 


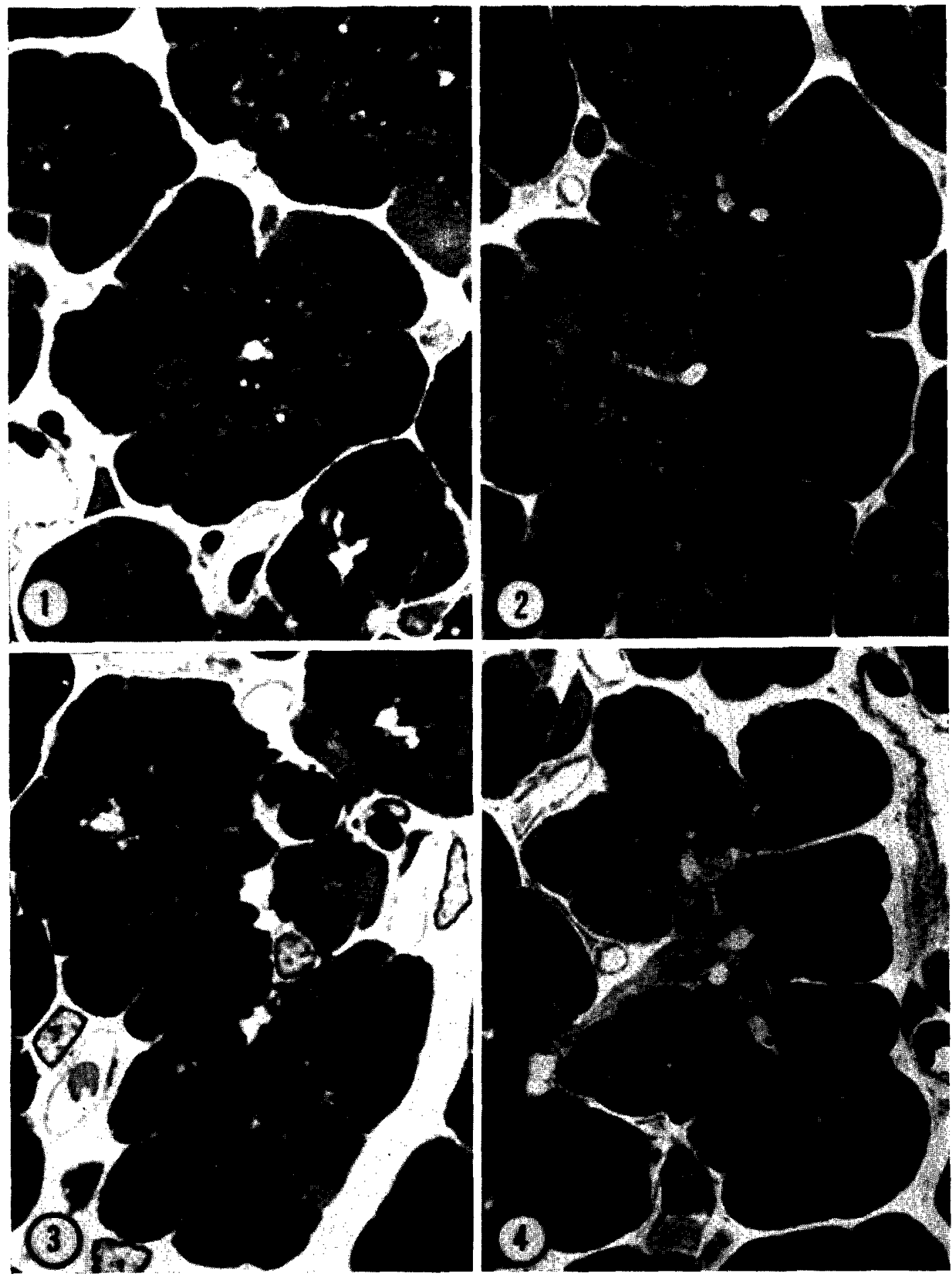

Fic. 1. Control acinar cells. They are uniform in size. The negative image of the Golgi complex is seen at supranuclear positions. The nucleolus is prominent in many cells. $\times 1000$.

Fig. 2. Control acinar cells from the rat receiving poly (A:U). Note the more prominent negative image of the Golgi complex than the control. $\times 1000$. 
of ${ }^{3} \mathrm{H}$-phe, the animals were killed by a blow to the base of the skull, and the pancreas was exposed and excised. From the tail of the pancreas all visible adipose and fibrous tissues were removed rapidly. The pancreatic tissues were weighed, and rapidly homogenized in distilled water at $4^{\circ} \mathrm{C}$ to make a concentration of $10 \mathrm{mg}$ per $\mathrm{ml}$. Acid-soluble fractions derived from the previous procedure were added to the Bray's solution (Bray, 1960). Samples were counted in a Packard Tri-Carb 3320 liquid scintillation spectrometer. After counting, the quench correction was accomplished by using the external standard method.

Since the pancreatic exocrine cells contain varying amounts of exportable proteins which change under different experimental conditions, all biochemical results will be expressed in terms of micrograms of DNA which serves as an index of tissue cellularity. For determination of DNA content, the diphenylamine reaction of Burton was used (1968). Results were compared with data derived from calf thymus DNA as standard. For determination of total protein content, the Folin phenol reagent was used (Lowry, Rosebrough, Farr, and Randall, 1951). Results were standardized by using bovine serum albumin.

Alpha amylase is one of the major exportable proteins of pancreas and is more stable and easily purified than other pancreatic proteins (Cozzone and MarchisMouren, 1967). This enzyme can, therefore, serve as a convenient indicator of the synthetic activity of this gland. Amylase contents were also compared in each group on the basis of DNA by using a colorimetric procedure for $\alpha$-amylase activity by using the Cibachron Blue F3 GA-Amylose (Roche Diagnostics, Div. of Hoffman La Roche, Inc., New Jersey) which allows a direct determination of amylase content in samples (Dalal and Winsten, 1971; Morawa and Han, 1974).

Upon sacrifice, blood samples of approximately $8 \mu \mathrm{l}$ per animal were collected in heparinized capillary tubes (Clay Adams, $75 \times 1.2 \mathrm{~mm}$ ). After blood was drawn from the left ventricle, the tube was placed in a scintillation vial and pulverizcd. The matcrial was processed according to the method of Frenkel, Whalley, Knorpp, and Korst (1962), and counted in a Packard Tri-Carb 3320 liquid scintillation spectrometer. No significant differences in radioactivity of the blood were found among the rats at the time of sacrifice.

\section{RESULTS AND OBSERVATIONS}

\section{Structural Modifications}

Detailed descriptions on the structural modifications of pancreatic acinar cells after hypoxic exposure have been made in a previous publication (Kim and Han, 1975). Therefore, only those characteristics pertinent to changes believed to have been induced by poly $(\mathrm{A}: \mathrm{U})$ treatment will be described below.

Light microscopic observations. The appearance of control cells was similar betwcen those receiving and not receiving poly $(A: U)$. The only notable difference between the two groups was that the negative image of the Golgi complex was often more prominent in cells under the influence of poly (A:U) [cf. Figs. 1 and 2].

\footnotetext{
Fic. 3. Hypoxic acinar cells. The cells contain numerous zymogen granules of decreased density and irrcgular size. Cytosegresomes are seen in some acinar cells (arrow). $\times 1000$.

Fic. 4. Hypoxic acinar cells from the rat receiving poly $(A: U)$. The cells containing smaller zymogen granules that are fewer in number than in hypoxic cells (Fig. 3 ). The enlarged Golgi complex is clearly seen in most cells and the nucleoli are prominent. $\times 1000$.
} 
Compared to the minor difference found in control glands, cells from hypoxic glands given poly (A:U) exhibited much more exaggerated changes. The cells after poly ( $\mathrm{A}: \mathrm{U}$ ) injection had smaller zymogen granules that were fewer in number than in hypoxic cells (Figs. 3 and 4). The Golgi complex appeared clearly cnlarged in almost all cells, and the number and size of nucleoli were notably larger than those in hypoxic cells not given poly (A:U).

Nucleolar index. The nucleolar index of control cells was 73, whereas that of poly (A:U)-treated ones was 88 , a $21 \%$ increase $(P<0.001)$ of the index (Table I). Acinar cells from hypoxic rats had a nucleolar index of 61 . However, the index rose to 85 in the hypoxic glands after poly (A:U) administration, representing a $40 \%$ increase. In fact, the nucleolar index of hypoxic cells given poly (A:U) was $117 \%$ of the pair-fed control $(P<0.001)$.

General ultrastructure. At low magnifications, the appearance of acinar cells of the control and hypoxic glands confirmed earlier descriptions of similar cells in that, compared to the control, hypoxic cells contained more numerous autophagic vacuoles and zymogen granules some of which were bizonal in character (cf. Figs. 5 and 7). The Golgi complex was extensive in control cells but was diminished in size and extent of its organization in hypoxic cells (Figs. 9 and 11). In acinar cells taken from rats receiving poly (A:U), zymogen granules were generally fewer in numbers, and the Golgi complex appeared hypertrophic (Figs. 6 and 8).

The nucleus from both control and hypoxic rats after poly A: $\mathrm{U}$ administration was of round shape and located in the basal portion of the cell. The nucleolus of poly (A:U)-treated cells both from hypoxic and control rats appeared larger in size than that of untreated ones. In fact, the size and appearance of nucleoli from hypoxic cells given poly $(\mathrm{A}: \mathrm{U})$ were similar to those that were seen in poly (A:U)-treated control cells and, therefore, could not be distinguished from each other. This corroborates with results from nucleolar index determination.

Changes in the Golgi complex. The Golgi apparatus from the control cells receiving (poly A:U) demonstrated extensively developed and numerous parallel stacks of the Golgi lamellae with many transport vesicles (cf. Figs. 9 and 10). The condensing vacuoles associated with the distal portion of the Golgi cisternae appeared to be increased in number (Fig. 10). The Golgi complex in hypoxic cells given poly ( $\mathrm{A}: \mathrm{U})$ was similar in many respects to that of the poly (A:U)-treated control cells (Fig. 12). Compared to the control (Fig. 9) or hypoxic cells (Fig. 11), the number of condensing vacuoles appeared to be greater. Those cisternae located in the proximal portion (REK side) of the Golgi complex appeared to contain a limited amount of flocculent material, which increased in amount within the distal or concave side of the complex (Fig. 12, arrows).

On occasion, cells from the control rats given poly (A:U) had a cytoplasm in which numerous zymogen granules were present within the cisternae of the RER (Fig. 13). In such cells, the RER appeared dilated and the granules that were contained in the RER werc smaller than regular zymogen granules. The number of granules present in a profile of the RER ranged from one to half a dozen or more. 

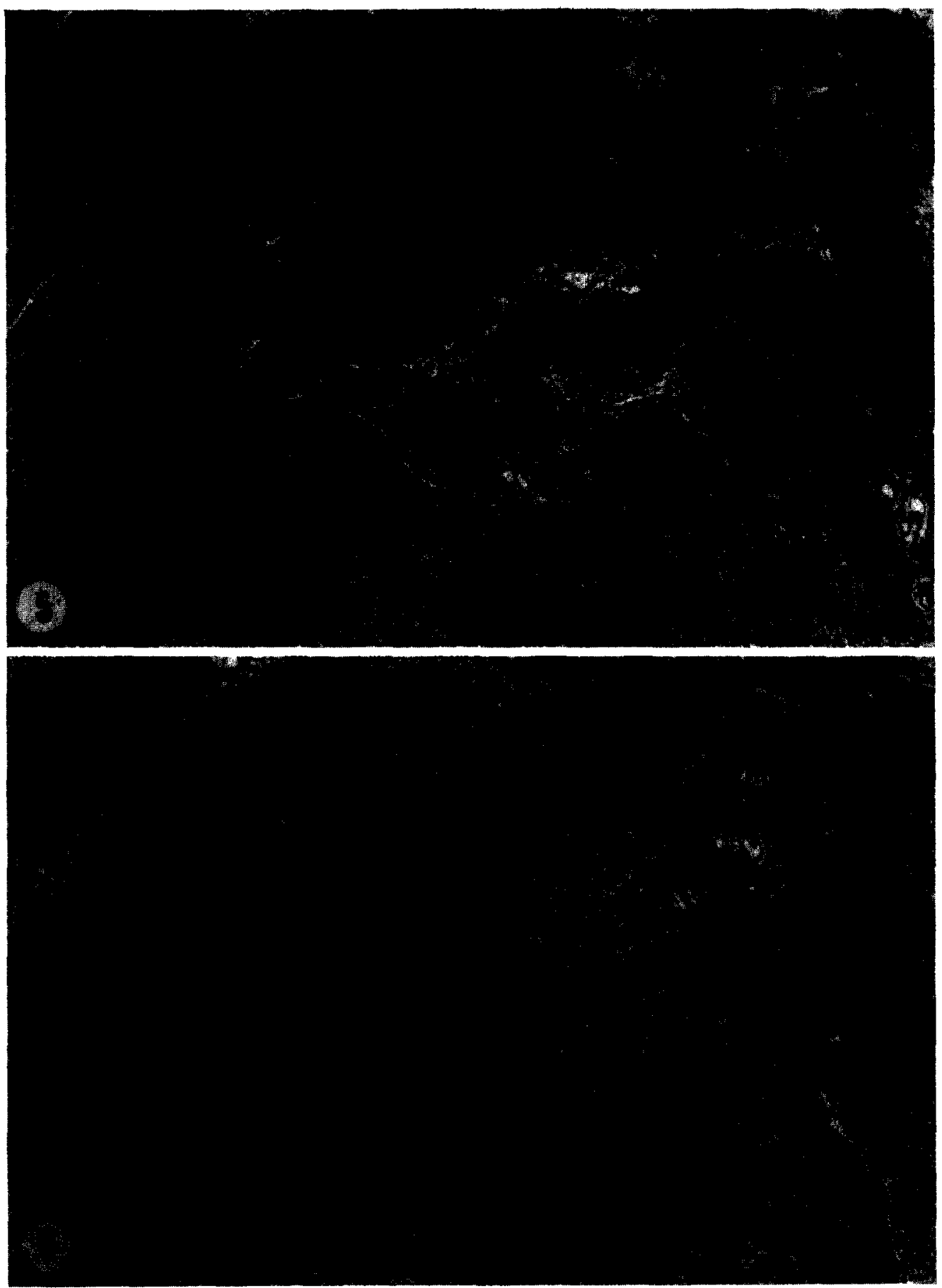

Fic. 5. A low-power electron micrograph of a control acinar cell, showing the usual cytoplasmic structures characteristic to this cell. The Golgi complex is well developed and nucleoli are prominent. $\times 9600$.

Fig. 6. A low-power electron micrograph of a control acinar cell given poly (A:U). Zymogen granules are reduced in number and size, and the Golgi complex is hypertrophic. Two nucleoli adjacent to the nuclear envelope are seen. $\times 8800$. 


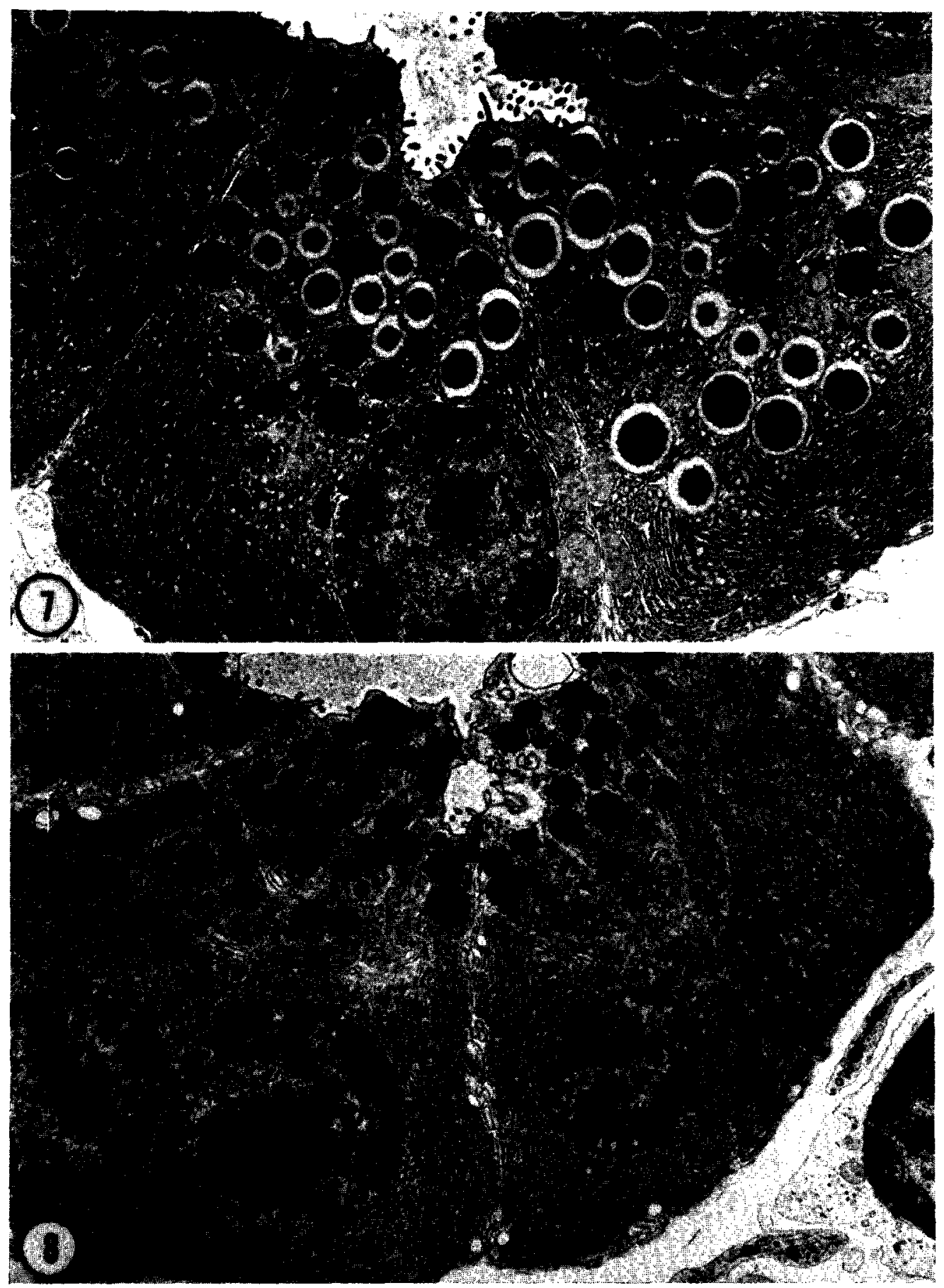

Fic. 7. A low-power electron micrograph of hypoxic acinar cells. They show zymogen granules many of which have an electronlucent peripheral region. Also note the larger number of autophagic vacuoles than in the control cell (Fig. 5). $\times 5600$.

Frg. 8. Hypoxic acinar cells from the rat receiving poly $(\mathrm{A}: \mathrm{U})$. A low-power electron micrograph of hypoxic acinar cells after administration of poly $(A: U)$. Note the hypertrophic Golgi complex. Zymogen granules are fewer in number when compared with the acinar cell from the rat not receiving poly $(A: U)$. One of the nuclei contains a prominent nucleolus. $\times 5600$. 


\section{TABLE I}

Empecis ur Poly (A:U) on Rat Pancreas: Nucleolar Index of Hypoxic and Patr-Fed Control Glands ${ }^{a}$

\begin{tabular}{|c|c|c|c|}
\hline Group & $\frac{\text { No. of nucleoli }}{\text { No. of nuclei }} \times 100(\mathrm{SD})$ & $\begin{array}{l}\% \text { of } \\
\text { Control }\end{array}$ & $P$ \\
\hline Hypoxic & $60.6( \pm 3.58)$ & 83.5 & $<0.001$ \\
\hline $\begin{array}{l}\text { Hypoxic } \overline{\mathrm{C}} \\
\text { Poly (A:U) }\end{array}$ & $85.0( \pm 4.31)$ & 117.1 & $<0.001$ \\
\hline $\begin{array}{l}\text { Control } \bar{c} \\
\text { Poly }(\mathrm{A}: \mathrm{U})\end{array}$ & $87.7( \pm 4.28)$ & 120.8 & $<0.001$ \\
\hline Control & $72.6( \pm 4.84)$ & 100 & \\
\hline
\end{tabular}

a Changes in the nucleolar index of the rats after administration of poly (A: U) when compared with the animals not receiving poly (A:U). Results are derived from counting about 4500 nuclei from five animals in each group. A statistically significant increase in nucleolar index is evident in the rats receiving poly $(A: U)$.

\section{Biochemical Results}

DNA content. The DNA content of the control and hypoxic groups receiving poly (A:U), was $129 \%$ and $108 \%$, respectively, of those that did not receive poly (A:U) (Table II). However, the difference between hypoxic group and hypoxic group receiving poly $(\mathrm{A}: \mathrm{U})$ was insignificant $(P<0.3)$. This indicates that pancreatic exocrine cells of the control after poly $(A: U)$ administration are smaller than those not receiving poly (A: $U$ ), and that such a difference in cell size may not be present in hypoxic cells.

Total protein and amylase contents. The amount of total protein after poly (A:U) administration, when expressed in terms of micrograms protein per microgram DNA, was reduced to $68 \%$ and $75 \%$ in control and hypoxic groups, respectively, from those not receiving poly (A:U) (Fig. 14). The amylase content in the groups receiving poly $(\mathrm{A}: \mathrm{U})$ was also reduced to $89 \%$ in control and to

TABLE II

Effects of Poly (A:U) on Rat Pancreas: DNa Contents of Hypoxic and Pair-fed Control Glands ${ }^{a}$

\begin{tabular}{ccc} 
Group & $\begin{array}{c}\text { DNA (SD) } \\
\text { Amount }(\mu \mathrm{g}) / \mathrm{mg} \text { tissue }\end{array}$ & $\begin{array}{c}\% \text { of } \\
\text { Control }\end{array}$ \\
\hline $\begin{array}{l}\text { Hypoxic } \\
\text { Hypoxic } \overline{\mathrm{c}} \\
\text { Poly }(\mathrm{A}: \mathrm{U}) \\
\text { Control } \overline{\mathrm{c}} \\
\text { Poly }(\mathrm{A}: \mathrm{U})\end{array}$ & $1.3( \pm 0.15)$ & 92.9 \\
Control & $1.4( \pm 0.15)$ & 100 \\
& $1.8( \pm 0.05)$ & 128.6 \\
& $1.4( \pm 0.10)$ & 100
\end{tabular}

a DNA contents of the pancreas from hypoxic and control rats with or without poly (A:U) administration. The amount of DNA present in the pancreas is increased in the control group after poly (A: U) administration, indicating a reduction in cell size in this group. 


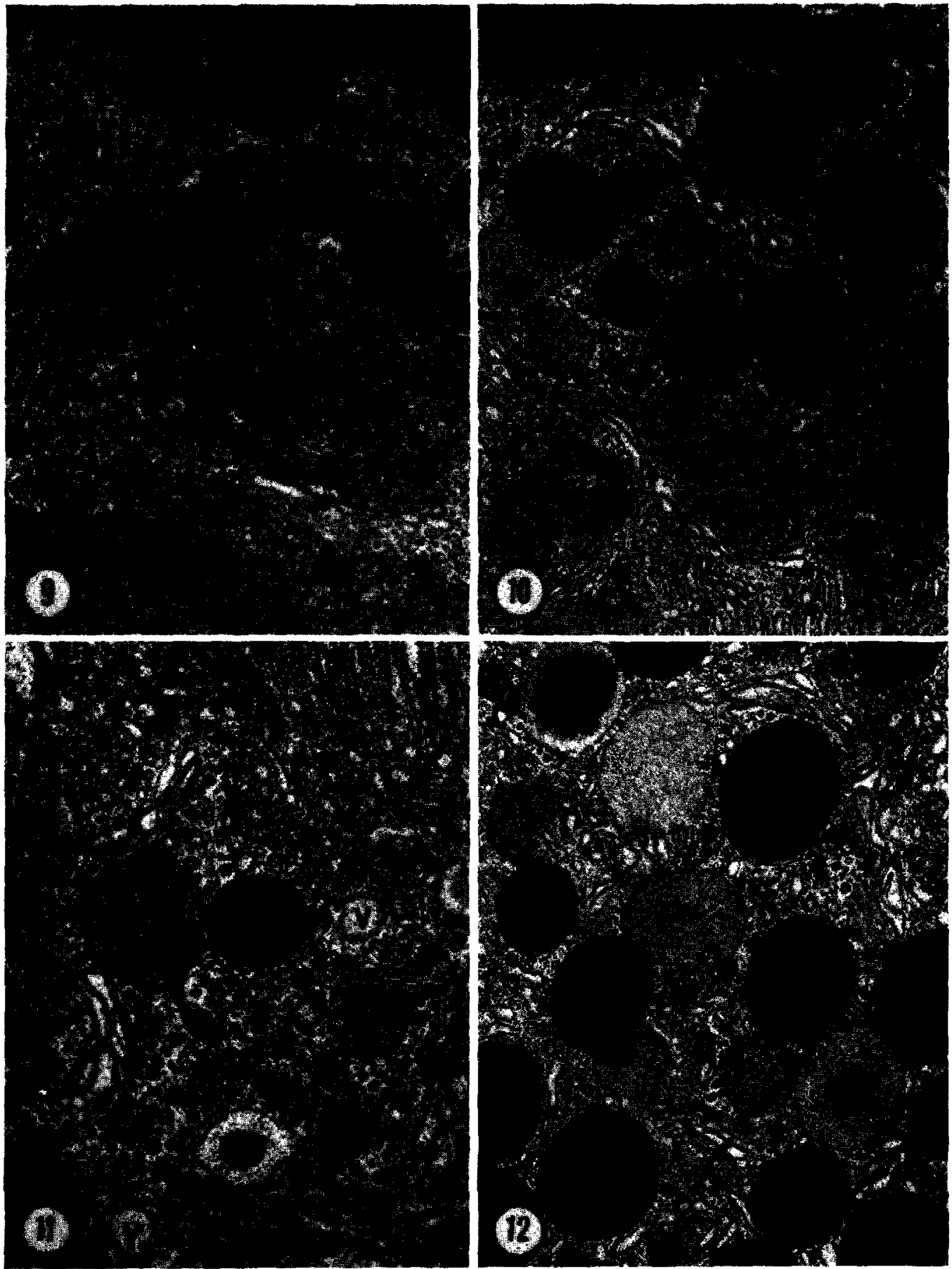

FIG. 9. A Golgi complex of a control acinar cell. $\times 15,000$

FIG. 10. A Golgi complex of a control acinar cell from the rat receiving poly (A:U). It has numerous parallel stacks with many transport vesicles and condensing vactoles ( $\mathrm{c} v$ ). In some areas, Golgi cisternae are irregular and dilated. X15,000.

Fic. 11. A Golgi complex of an hypoxic acinar cell. In addition to the reduced size of this organelle (compare magnifications of Figs. 9 and 10 with 11), it shows irregularly dilated lamellae and electron-lucent vacuoles $(v) . \times 27,000$.

FIG. 12. The Golgi complex of an hypoxic acinar cell from the rat given poly (A:U). Note the complex lamellae and the increased number of condensing vacuoles (cv). X15,000. 


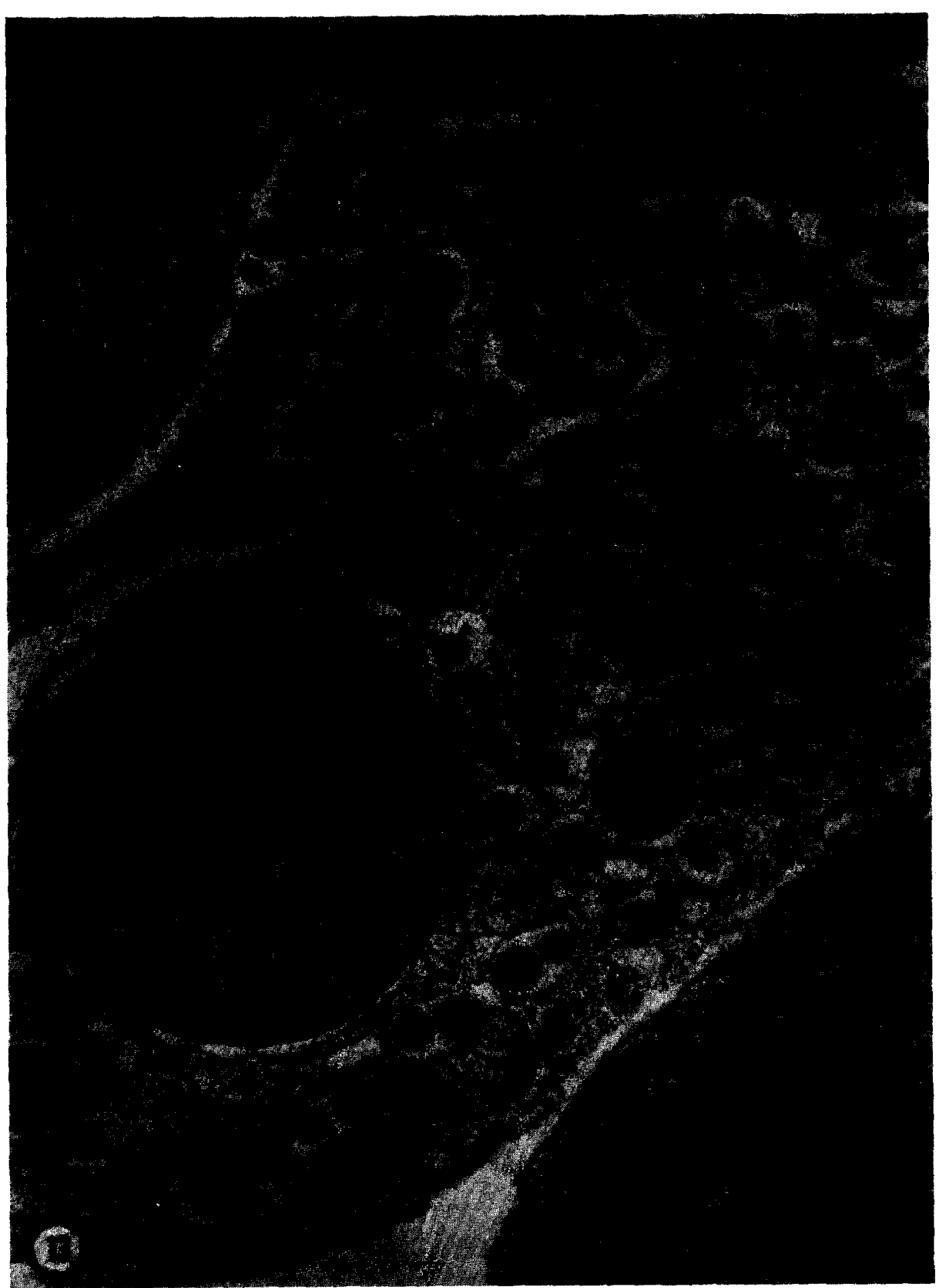

Fig. 13. Numerous small zymogen granules without a distinct membrane are present within cisternae of the RER. $\times 21,000$. 


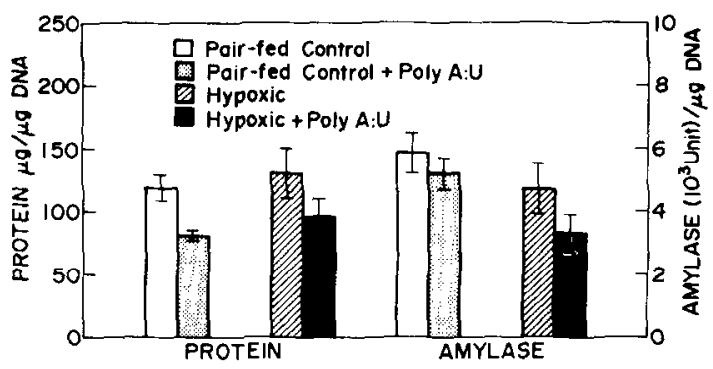

Fig. 14. Summary of the total protein and amylase contents in terms of $\mu$ gNA. In the control cells from the rat receiving poly $(\mathrm{A}: \mathrm{U})$, both total protein content and amylase content are reduced (68\% and $89 \%$, respectively). The hypoxic cells from the rat receiving poly (A:U) contain also reduced amounts of both total protein and amylase contents $(75 \%$ and $71 \%$, respectively). Ranges indicate standard deviations of arithmetic means.

$71 \%$ in experimental rats from those not given poly (A:U). The enzyme-toprotein ratio in control cells was increased by $29 \%$ after (poly $\mathrm{A}: \mathrm{U}$ ) treatment, and thus reflects a higher relative amylase content in poly (A:U)-treated control. However, this ratio was slightly lower in hypoxic rats given poly (A:U) $(95 \%)$.

Incorporation of ${ }^{3} \mathrm{H}$ Phe. Results from the analysis of ${ }^{3} \mathrm{H}$-phe incorporation into acid-precipitable and soluble fractions are recorded in Fig. 15. The control gland cells injected with poly $(\mathrm{A}: \mathrm{U})$ were lower in radioactivity $(68 \%)$ than those not injected with the nucleotide mixture. Similarly, the acid-soluble fraction from the poly ( $\mathrm{A}: \mathrm{U})$-treated control was $63 \%$ of the control not given poly $(A: U)$. When these data were normalized by equating the radioactivity levels of the soluble amino acid pools, the result indicated a $9 \%$ increase in poly (A:U)-treated controls. Therefore, the results suggest that poly (A:U), while having a limited stimulatory effect on ${ }^{3} \mathrm{H}$-phe incorporation into proteins in terms of the cell's intrinsic capacity for protein synthesis, might paradoxically suppress the total protein synthesis in control glands by a reduction of amino acid pool size apparently resulting from poly ( $A: U$ ) administration.

In contrast to the limited poly ( $A: U$ ) effect on control cells mentioned above, the acid-precipitable fraction from hypoxic cells given poly $A: U$ produced a considerable increase in radioactivity (172\% of hypoxic cells). At the same time, the difference in radioactivity of acid-soluble fraction between hypoxic cells without and with poly A:U was even greater than that found for the controls. The radioactivity of the acid-soluble fraction from hypoxic cells given poly $(\mathrm{A}: \mathrm{U})$ was only $54 \%$ of that of hypoxic cells without poly $(\mathrm{A}: \mathrm{U})$. When the difference in radinactivity of soluble fractions was adjusted as before, the normalized value showed that hypoxic cells given poly (A:U) were capable of incorporating ${ }^{3} \mathrm{H}$-phe into proteins at $320 \%$ efficiency of the ones without the benefit of poly $(A: U)$.

\section{DISCUSSION}

Structural evidence for stimulatory effects of poly $(A: U)$. The appearance of the Golgi complex, in both the control and hypoxic glands given poly (A:U), clearly indicates that this organelle, which plays a vital role in the packaging and condensation of secretory proteins (Jamieson and Palade, 1967a and b), 
is stimulated in its function. The changes in the size and structural organization of nucleoli as well as the increase in the nucleolar index also support the possibility that poly (A:U) may stimulate the production of ribosomal RNA precursors (Busch and Smetana, 1970). These are of particular interest, as the extent of such structural effects on hypoxic glands appears to be comparable to what is observed in the control.

Stimulation of enzyme release by poly $(A: U)$. Earlier work by Kim and Han (1972) suggested that pancreatic cells in normal and fluorouracil-treated rodents may respond to the administration of poly $(\mathrm{A}: \mathrm{U})$ by stimulating the release of zymogen granules. Results from the current study support this and demonstrate the reduction of total protein and amylase content in poly (A:U)-treated cells when expressed per unit weight of DNA. Although the mechanism of action of poly $(\mathrm{A}: \mathrm{U})$ in eliciting a stimulatory effect on the release of secretory products remains to be determined, it is of interest to note that the cyclic AMP levels after polynucleotide administration have been observed to increase in stimulated lymphoid organs (Braun and co-workers, 1971).

Since the polyribonucleotides used in this study are sticky molecules that are likely to be trapped by the plasma membrane, changes in membrane characteristics such as permeability could affect the release of cellular products. Thus, it is not impossible that an enhanced exocytosis may develop as a result of the exposure of secretory cells to poly ( $\mathrm{A}: \mathrm{U})$ molecules. Furthermore, there is recent evidence that indicates the penetration of cell membranes by some of the polyribonucleotide molecules (Schell, 1971 and 1972). Such a penetration of plasma membranes could conceivably lead to changes in the biophysical nature of intracellular membranes by the nucleotides.

That the plasma membrane of acinar cells may change its permeability characteristics under the influence of poly $(\mathrm{A}: \mathrm{U})$ is indicated clearly by the reduction of radioactivity in the acid-soluble fraction. The radioactivity in this fraction of hypoxic cells, as noted before (Kim and Han, 1975), is increased. Yet the

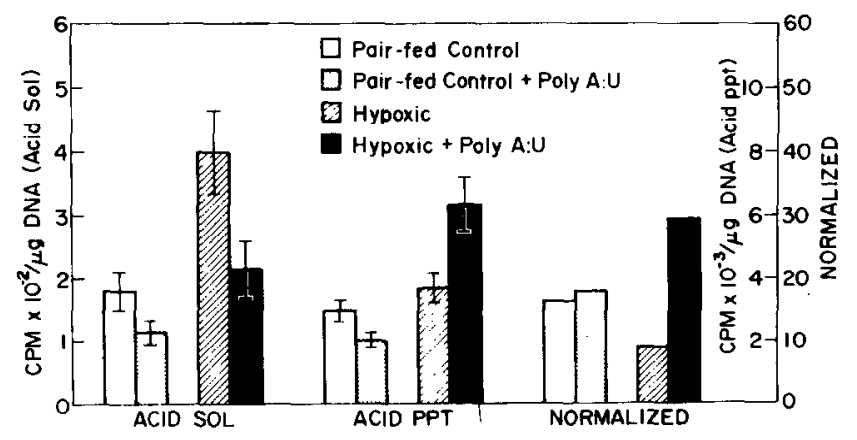

Fig. 15. Summary of the results of the ${ }^{3} \mathrm{H}$-phe incorporation. The incorporation of ${ }^{3} \mathrm{H}$-phe into protein in control cells from the rat receiving poly (A:U) is lower than that not receiving the nucleotides $(68 \%)$. On the contrary, hypoxic cells from the rat given poly (A:U) show a drastic increase of "H-ple incorporation (172\%). The radioactivily in acidsoluble fraction is reduced both in control cells from the rat receiving poly (A:U) (63\%) and in hypoxic cells from the rat given poly (A:U) (54\%). Ranges indicate standard deviation of arithmetic means. The normalized value which eliminates differences in intracellular precursor levels, shows a slight increases of ${ }^{3} \mathrm{H}$-phe incorporation in control cells from the rat receiving poly (A:U) (109\%), while this is drastically increased in hypoxic cells from the rat receiving poly $(A: U)(320 \%)$. 
radioactivity of acid-soluble fraction of both the control and hypoxic glands shows a rather drastic drop after poly ( $\mathrm{A}: \mathrm{U})$ administration.

Stimulated synthesis of proteins by poly $(A: U)$. The observed stimulation of protein synthesis in the hypoxic gland has occurred despite the reduced availability of ${ }^{3} \mathrm{H}$-phe. When the discrepancy in pool size is eliminated by equalizing radioactivities of soluble fractions, over $200 \%$ increase in synthetic activity is noted in the poly (A:U)-treated hypoxic glands, whereas only a slight increase is present in the control. It is difficult to rationalize at this time as to the reason why the poly $(\mathrm{A}: \mathrm{U})$ would have greater effect on the cells insulted by exposure to an hypoxic environment.

Recent work from this laboratory, however, tends to support the result of this study in that stimulatory effects of poly (A:U) on protein synthesis are greater in cells that have been exposed to adverse physiologic conditions (Han, 1973; Morawa and Han, 1974). It is tempting to speculate that the stimulatory effects of (poly A:U) may be manifested better in tissues where the cells might be loaded with molecules necessary for cytoplasmic repair function. The increase in autophagic bodies in pancreatic acinar cells from rats exposed to hypoxia has been adequately demonstrated in a previous paper (Kim and Han, 1975). Thus, it is possible that the breakdown products from autophagic processes may, if damaged cytoplasmic structures are to be reutilized during the recovery phase of the cells, accentuate poly $\mathrm{A}: \mathrm{U}$ effects.

Enhancement of protein biosynthesis by synthetic polyribonucleotide has been well-documented in the area of interferon production in bacterial (Colby, 1971) and various immune systems (Braun et al., 1967, 1971; Johnson et al., 1968, 1971 and Cone and Johnson, 1971 and 1972). Since these unnatural nucleotides cannot be regarded to have specific recognition sites in particular populations of Cells, the enhancement of protein synthesis by lymphoid or digestive gland cells after polyribonucleotide administration may involve nonspecific interactions between the cell surface and nucleotides. It should be noted, however, that there is a degree of specificity in terms of the effects elicited by a particular type of polyribonucleotides. For example, it is known that interferon production can be stimulated specifically by poly (I:C) (Colby, 1971). whereas poly (A:U) is more effective in lymphoid organs (Johnson et al., 1968 and 1971) and exocrine cells under certain conditions.

Inasmuch as one of the major problems in biomedical sciences is to find ways by which one could produce controlled and predictable modifications of cell function either in terms of stimulation or suppression, a continued study of the polyribonucleotide effects on cell structure and function would have a significant practical value for the future.

\section{ACKNOWLEDGMENTS}

The authors are indebted to Dr. John W. Bean, Professor Emcritus of Plysiology at Michigan whose advice enabled the fabrication of the hypoxic environment chamber used in this study.

We gratefully appreciate the able technical assistance provided hy Mrs. S. J. Auh and Mrs. Li-Fong Hwang.

This work is based on a Ph.D. thesis at The University of Michigan by the senior author.

Supported in part by U.S.P.H.S. Grant DE-03348. 


\section{REFERENCES}

Braun, W., and Nakano, M. (1967). Antibody formation: stimulation by polyadenylic and polycytidylic acids. Science $157,819-821$.

Braun, W., and Ishizura, M. (1971). Cyclic AMP and immune response. II. Phosphodiesterase inhibitors of polynucleotide effects on antibody formation. J. Immunol. 107, 1036-1042.

Braun, W., and Ishizuka, M., Yajima, Y., Webb, D., and Winchurch, R. (1971). Spectrum and mode of action of poly $\mathrm{A}: \mathrm{U}$ in the stimulation of immune responses. In "Biological Effects of Polynucleotides" (Beer, R. and Braun, W., Eds.), pp. 139-156. SpringerVerlag, New York.

Bray, G. A. (1960). A simple efficient liquid scintillator for counting aqueous solutions in a liquid scintillation counter. Anal. Biochem. 1, 279-285.

Burtos, K. (1968). Determination of DNA concentration with diphenylamine. In "Methods of Enzymology" (Grossman, L. and Moldave, K., Eds.), Vol. 12, pp. 163-169. Acadcmic Press, New York.

Busch, H., and Smetana, K. (1970). Effects of drugs and other agents on the nucleolus. In "The Nucleolus." (Busch, H. and Smetana, K., Eds.), pp. 472-510. Academic Press, New York.

CoLBY, C., JR. (1971). The induction of interferon by natural and synthetic polynucleotides. In "Progress in Nucleic Acid Research and Molecular Biolngy" (Davidson, J. N., and Cohn, W. E., Eds.), Academic Press, New York and London, 11, 1-32.

Cone, R. G., and Johnson, A. G. (1971). Regulation of the immune system by synthetic polynucleotides. III. Action on antigen-reactive cells of thymic origin. J. Exp. Med. 133, 665-676.

Cone, R. G., and Johnson, A. G. (1972). Regulation of the immune system by synthetic polynucleotides. IV. Amplification of proliferation of thymus-influened lymphocytes. Cell Immunol. 3, 283-293.

Cozzone, A., and Marchis-Mouren, G. (1967). Messenger ribonucleic and stability in rat pancreas and liver. Biochemistry 6, 3911-3917.

Dalal, F. R., and Winsten, S. (1971). Laboratory evaluation of chromogenic amylase method. Clin. Chim. Acta 32, 327-332.

Frenkel, E. P., Whalley, B. E., KNorpp, C. T., and Korst, D. R. (1962). On the counting of tritiated thymidine in tissues. J. Lab. Clin. Med. 59, 174-178.

HAN, S. S. (1973). Effects of 5-fluorouracil on the parotid and pancreas of rodents. In "Symposium on the Mechanism of Exocrine Secretion." (Han, S. S., and Suddick, R. P., Eds.), pp. 102-108. Univ. of Michigan Press.

Han, S. S., and Hwang, L. (1974). Unpublished observations.

Hinrichs, H. R., Peterson, R. O., and Baserga, R. (1964). Incorporation of thymidine into DNA of mouse organs. Arch. Pathol. 78, 245-253.

JAMIESON, J. D., and PALADE, G. E. (1967a). Intracellular transport of secretory proteins in the pancreatic exocrine cell. I. Role of the peripheral elements of the Golgi complex. J. Cell Bivl. 34, 577-596.

Jamieson, J. D., and Palade, G. E. (1967b). Intracellular transport of secretory proteins in the pancreatic exocrine cell. II. Transport to condensing vacuoles and zymogen granules. J. Cell Biol. 34, 597-615.

Johnson, A. G., Schmidtke, J. R., Merritt, K., and Han, I. (1968). Enhancement of antibody formation by nucleic acids and their derivatives. In "Nucleic Acids in Immunology" (Plescia, O. J., and Braun, W., F.ds), pp. 379-385. Springer-Verlag, New York.

Johnson, H. G., and Johnson, A. G. (1971). Regulation of the immune system by synthetic polynucleotides, II. Action on peritoneal exudate cells. J. Exp. Med. 133, 649-664.

KIM, Y. G., and HAN, S. S. (1975). Studies on hypoxia IX. Ultrastructural and biochemical effects of prolonged exposure on rat pancreas. Submitted. In press, Amer. J. Anat.

KIM, M. K., and HAN, S. S. (1972). Effects of 5-fluorouracil on exocrine glands. I. Gland weights in mice receiving synthetic polynucleotides. Proc. Soc. Exp. Biol. Med. 139, 12461251 .

Lowry, O. H., Rosebrough, N. J., Farr, A. L., and Randall, R. J. (1951). Protein measurement with the Folin phenol reagent. J. Biol. Chem. 193, 265-275. 
LuFT, J. H. (1961). Improvements in epoxy resin emedding methods. J. Biophys. Biochem. Cytol. 9, 409-414.

Morawa, A. P. (1973). An ultrastructural and biochemical study of the effect of hypoxia upon rat parotid glands. University of Michigan Ph.D. dissertation.

MORAwA, A. P., and HAN, S. S. (1974). Studies on hypoxia. VIII. Ultrastructural and biochemical effects of prolonged exposure on rat parotid glands. Exp. Mol. Pathol. 21, 268-287.

Pfrender, A. R., (1973). Effects of methyl mercury cysteine on adult rat brain: Cytopathology and in vivo protein synthesis. University of Michigan Ph.D. dissertation.

Reynolds, E. S. (1963). The use of lead citrate at high $\mathrm{pH}$ as an electron opaque stain in electron microscopy, J. Cell Biol. 17, 208-212.

Schell, P. L. (1971). Uptake of polynucleotides by intact mammalian cells. VIII. Synthetic homoribonpolynucleotides. Biochim. Biophys. Acta 240, 472-484.

Schell, P. L. (1972). Uptake of polynucleotides by intact mammalian cells. XI. pHdependent permeability changes for synthetic ribopolymers. Biochim. Biophys. Acta. 262, $467-475$. 